\title{
Nutrition Education with Android-Based Application Media to Increase Knowledge, Attitudes, and Behaviors of Pregnant Women about Chronic Energy Deficiency (KEK)
}

\author{
Wa Ode Sri Wati Lestari \\ Department of Midwifery, Post Graduate School, Hasanuddin University, Indonesia \\ Coresponding author email: lestariwosw19p@student.unhas.ac.id \\ Syafruddin Syarif \\ Faculty of Engineering, Hasanuddin University, Indonesia \\ Email: syafruddin.s@eng.unhas.ac.id

\section{Healthy Hidayanty} \\ Department of Nutrition, Faculty of Public Health, Hasanuddin University, Indonesia \\ Email: hhidayanty@yahoo.com \\ Aminuddin \\ Department of Nutrition, Faculty of Medicine, Hasanuddin University, Indonesia \\ Email: aminuddin@med.unhas.ac.id
}

Sri Ramadany

Faculty of Medicine, Hasanuddin University, Indonesia

Email: sriramadanifk@gmail.com

\begin{abstract}
Pregnant women are a very vulnerable group to nutritional problems. The lack of knowledge, attitude, and behavior towards nutrition is the main cause of KEK (chronic energy deficiency) in pregnant women. The purpose of this study was to design an android-based application based on a needs analysis to improve nutritional knowledge and attitudes of pregnant women about KEK. The research method was qualitative research, while the design used a combined method between Research and Development $(R \& D)$ and Pre-Experiment methods with one group pre-test and post-test designs. The results of the data analysis showed that the knowledge, attitudes, and behavior of pregnant women increased by 72\%, 78\%, and 39\%, respectively. The p-value of the McNemar test results for the variables of knowledge, attitude, and behavior was $0.000<\alpha(0.05)$, indicating there were differences in the knowledge, attitude, and behavior of pregnant women before and after using the application $(p<\alpha)$. It was concluded that nutrition education with Android-based application media influenced the knowledge, attitudes, and behavior of pregnant women, that is, to increase the knowledge, attitudes, and behavior of pregnant women about KEK in Meo - Meo Public Health center, Baubau City.
\end{abstract}

Keywords---attitudes, behavior, knowledge, nutrition, pregnant women.

\section{Introduction}

Chronic Energy Shortage (KEK) is one of the health problems in the world, especially in developing countries. Chronic Energy Deficiency occurs when the intake of energy, protein, or even both is not sufficient for the body's needs. Chronic Energy Deficiency affects many women of childbearing age (WUS) aged 15-45 years. Chronic energy deficiency can also affect pregnant women who have risk factors for KEK (Farida et al., 2020). Based on 
WHO data in 2016, the prevalence of KEK in pregnancy globally is $35-37 \%$, where the highest rate is in the third trimester compared to the first and second trimesters of pregnancy. WHO noted that $40 \%$ of maternal deaths in developing countries are related to KEK (Erlinawati \& Masturo, 2018).

In Indonesia, the nutritional intake of pregnant women is concerning as well, where the proportion of pregnant women with an energy sufficiency level of less than $70 \%$, the energy adequacy rate (AKE) was slightly higher in rural areas than in urban areas, namely $52.9 \%$ compared to $51.5 \%$. Meanwhile, the proportion of pregnant women with a protein adequacy level of less than $80 \%$, the protein adequacy rate (AKP) was also higher in rural areas compared to urban areas, namely $55.7 \%$ compared to $49.6 \%$. (Ministry of Health, 2017). Similar data is shown by the Indonesian Basic Health Research in 2016, showing the prevalence of chronic energy deficiency in pregnant women (KEK) at the national level as much as $16.2 \%$. According to the 2017 Nutritional Status Monitoring (PSG) survey, the percentage of pregnant women with a risk of KEK is 14.8\% (Ministry of Health, 2017; Agustian, 2010; Andriani, 2015; Kartikasari et al., 2013).

Meanwhile, data for pregnant women who experienced KEK obtained at the Baubau City Health Office in 2019 showed that out of 3516 pregnant women who came to have their pregnancy checked, there were 475 or $16.28 \%$ of pregnant women who experienced chronic energy deficiency (KEK). Meanwhile, data from Meo-Meo Health Center in Baubau City in 2019, which was intended as the location of the author's research, showed that of the 367 pregnant women who came to have their pregnancy checked, there were 53 pregnant women or $14.44 \%$ experiencing KEK.

Theoretically, chronic energy deficiency (KEK) in pregnant women is caused by several factors, both direct causes and indirect causes. The direct causes are insufficient nutritional consumption and infectious diseases, while the indirect causes are insufficient food supply, education level, the prevalence of not working mothers, economic status, and mother's lack of knowledge and attitudes about nutrition during pregnancy, which greatly affect the fulfillment of mother's nutrition every day (Sungurtekin et al., 2004; Wild et al., 2010).

In connection with this problem, nutrition education efforts are very well provided, as a form of approach carried out in nutrition care to help individuals so that they gain better knowledge about the nutrition needed, nutritional problems faced, how to solve problems and to choose the most suitable solution (Suryani \& Ardian, 2020). For examples, Zaki \& Sari (2019) in his research "Social Media-Based Nutrition Education, Increasing Knowledge and Protein Energy Intake with Chronic Energy Deficiency (KEK)" showed that giving nutrition education interventions 8 times for 2 weeks resulted in a $74.1 \%$ increased knowledge in urban and in rural groups $85.7 \%$, as well as an increase in the average energy intake in urban and rural groups (Farida et al., 2020; Sabilla et al., 2020; Krisdiani et al., 2020). Yulianasari et al., (2019) on "The Effect of Nutrition Education with Booklet Media on Changes in Adolescent Behavior Related to the Prevention of Chronic Energy Deficiency" found that nutrition education using booklet media was quite effective in increasing adolescent knowledge, practices, and attitudes.

The implementation of counseling, information, and education (IEC) that has been taking place in health services has been quite good, as shown by Tempali \& Sumiaty (2019) on "The Role of Midwives Education in Preventing Chronic Energy Deficiency (KEK) in Pregnant Women in Central Sulawesi Province" whose results showed that there is a positive relationship between the role of midwife education and the prevention of chronic energy deficiency (KEK) in pregnant women in Central Sulawesi province. However, such studies in which their interventions were conducted by midwives have prominent limitations, namely that midwives as extension agents have limited time to provide education so that the information received by pregnant women is also limited. Therefore, it is necessary to develop nutrition education methods for pregnant women that are more effective, practical, and following the needs of pregnant women (Bath et al., 2013; Garshasbi \& Zadeh, 2005).

In that regard, the development of technology is expected to be able to facilitate health services for all needs as well as the spread of health information and knowledge quickly (Hayurani et al., 2019). And in concern with that, android-based applications can provide information more quickly and can be used and accessed anytime and anywhere (Sayekti et al., 2020).

Research conducted by Nurhemah (2018), on "The Effect of Smartphone Use and Virtual Classroom on Conceptual Knowledge and Learning Independence of Students of Public Senior High School 2 South Tangerang asserted that learning using Smartphone media was better than the Expository learning model, as seen from the average value of independence. Those of students learning using smartphones had increased from $60.56 \%$ to $65.28 \%$ while the average values of those learning by expository learning model were lower, $46.39 \%$ to $54.94 \%$. Sayekti et al., (2020) in their research entitled "Education Media for Android-Based Pregnancy Hazard Signs to Increase Knowledge of Pregnant Women", found that by Android-based Pregnancy Hazard Education Media Interventions maternal knowledge increased by $15.50 \%$. Likewise, as asserted by Perdana et al. (2018), android-based nutrition education media was better than other media in improving balanced nutrition knowledge, attitude, and practice, as evidenced by the results. Before the intervention, school children's knowledge, positive attitudes, and well-balanced 
nutrition practices were successively at $72.9 \%, 78.5 \%, 54.9 \%$ and increased by $11.8 \%, 5.5 \%$ and $15.9 \%$ after the intervention.

Based on the description above, the researcher was interested in researching the use of Android-based applications that were specifically designed based on a needs analysis to improve nutritional knowledge and attitudes of pregnant women about chronic energy deficiency (KEK), with the title "Nutrition Education with Android-Based Application Media to Increase Knowledge, Attitudes, and Behaviors of Pregnant Women About Chronic Energy Deficiency (KEK) at the Meo-Meo Community Health Center, Baubau City".

\section{Research Methods}

This research method was quantitative research, while the research design used a combined method between Research and Development (R\&D) and Pre-Experimental methods with one group pre-test and post-test designs. The population in this study was all pregnant women in the first and second trimesters who came to have their pregnancies checked at the Meo-Meo Community Health Center from July to September 2020. Sample for Developing Android-Based Nutrition Education Media Designs to Improve Knowledge and Attitudes of Pregnant Women about Chronic Energy Deficiency (KEK) in this study was pregnant women who came to check their pregnancy as many as 36 respondents. This study used Non-Probability Sampling, that is, purposive sampling technique where the sample selection was based on researcher's consideration so that to obtain sample representative to the population and following researcher's need can be obtained (Sugiyono, 2008; Sugiyono, 2007).

The data collection technique was done by asking pregnant women to download the Nutrition of pregnant women Nutrition Application on their respective cellphones, then a pre-test was carried out to measure knowledge, while the mother's attitude was measured using a questionnaire, checklist sheet, and food recall 24 hours before the intervention was carried out. After that, the respondents were asked to open the material in the Nutrition of pregnant women application while a brief explanation about it was given by the researcher for some 20 minutes so that mothers can understand how to open the material contained in the application. The monitoring was conducted twice a week for 2 weeks of intervention (Batalden \& Stoltz, 1993; Malterud, 2001; Mulyani et al., 2017). A post-test was last conducted after the completion of the whole intervention by measuring knowledge using a questionnaire, attitudes by checklist sheet, and a 24-hour food recall on the 14th day after the intervention was given.

\section{Results}

1) The effect of Android-Based Nutrition Education Application on Pregnant Women Knowledge of Chronic Energy Deficiency (KEK) at the Meo - Meo Community Health Center, Baubau City.

Table 1

The Effect of the use of Android-Based Nutrition Education Applications on Knowledge of Pregnant Women $(\mathrm{n}=36)$

\begin{tabular}{lllll}
\hline \multirow{2}{*}{ Pre Knowledge } & \multicolumn{2}{c}{ Post Knowledge } & \multirow{2}{*}{ Total } & p-value* \\
\cline { 2 - 4 } & Less & Good & $26(72 \%)$ & \multirow{2}{*}{0.000} \\
Less & $0(0 \%)$ & $26(72 \%)$ & $10(29 \%)$ & \\
Good & $0(0 \%)$ & $10(29 \%)$ & $36(100 \%)$ & \\
Total & $0(0 \%)$ & $36(100 \%)$ & & \\
\hline
\end{tabular}

* McNemar test

The results of statistical tests in table 1 showed that respondents who had less knowledge before being given intervention and turned into good knowledge after being given intervention were $72 \%$. Respondents who had good knowledge before the intervention and were still good after the intervention was $29 \%$. The $p$-value of the McNemar test result was 0.000 which was less than $\alpha(0.05)$, so it can be concluded that there were differences in the knowledge of pregnant women before and after using the application $(p<\alpha)$. The results of this study indicated that $\mathrm{H} 0$ was rejected, which meant that there was an effect of using android-based nutrition education applications on the knowledge of pregnant women about Chronic Energy Deficiency (KEK) at the Meo - Meo Community Health Center, Baubau City. 
2) The effect of Android-Based Nutrition Education Application on the Attitudes of Pregnant Women About Chronic Energy Deficiency (KEK) in the Meo - Meo Community Health Center, Baubau City

Table 2

Effect of the use of Android-Based Nutrition Education Applications on the attitudes of pregnant women $(\mathrm{n}=36)$

\begin{tabular}{|c|c|c|c|c|}
\hline \multirow{2}{*}{ Pre attitude } & \multicolumn{2}{|c|}{ Post attitude } & \multirow{2}{*}{ Total } & \multirow{2}{*}{$p$-value * } \\
\hline & Unfavorable & Favorable & & \\
\hline Unfavorable & $0(0 \%)$ & $28(78 \%)$ & $28(78 \%)$ & \\
\hline Favourable & $0(0 \%)$ & $8(22 \%)$ & $8(22 \%)$ & 0.000 \\
\hline Total & $0(0 \%)$ & $36(100 \%)$ & $36(100 \%)$ & \\
\hline
\end{tabular}

*McNemartest

The results of the statistical test in table 2 showed that the respondents who had an unfavorable attitude before being given the intervention and changed to a favorable attitude after being given the intervention were $78 \%$. Respondents who had a favorable attitude before the intervention and remained favorable after the intervention was $22 \%$. The $p$ $v$ alue of the McNemar test result was 0.000 which was less than $\alpha(0.05)$, so it could be concluded that there were differences in the attitudes of pregnant women before and after using the application $(p<\alpha)$. The results of this study indicated that $\mathrm{H} 0$ was rejected, which meant that there was an effect of using android-based nutrition education applications on the attitude of pregnant women about Chronic Energy Deficiency (KEK) at the Meo - Meo Community Health Center, Baubau City.

3) The Effect of Android-Based Nutrition Education Applications on Behavior of Pregnant Women About Chronic Energy Deficiency (KEK) at the Meo - Meo Community Health Center, Baubau City

Table 3

Effect of the use of Android-Based Nutrition Education Applications on Pregnant Mother Behavior $(\mathrm{n}=36)$

\begin{tabular}{lllll}
\hline \multirow{2}{*}{ Pre behavior } & \multicolumn{2}{c}{ Post behavior } & \multirow{2}{*}{ Total } & \multirow{2}{*}{ p-value val $^{*}$} \\
\cline { 2 - 3 } & Deficit & Normal/above & & \\
\hline Deficit & $12(33 \%)$ & $14(39 \%)$ & $26(72 \%)$ & \\
Normal/above & $1(3 \%)$ & $9(25 \%)$ & $10(28 \%)$ & 0.001 \\
Total & $13(36 \%)$ & $23(64 \%)$ & $36(100 \%)$ & \\
\hline
\end{tabular}

*McNemar test

The results of statistical tests in table 3.6 showed that respondents who had a deficit eating behavior before being given the intervention and changed to normal/ more eating behavior after being given the intervention were $39 \%$. Respondents who have normal/ more eating behavior before the intervention and remain normal/ more after the intervention was $25 \%$. The $p$-value of the McNemar test result is 0.001 which was less than $\alpha(0.05)$, so it could be concluded that there was no difference in the eating behavior of pregnant women before and after using the application $(\mathrm{p}<\alpha)$. The results of this study indicated that $\mathrm{H} 0$ was rejected, which meant that there was an effect of the use of androids-based nutrition education applications on the behavior of pregnant women about Chronic Energy Deficiency (KEK) at the Meo - Meo Community Health Center, Baubau City.

4) Nutrition Education application for pregnant women to increase knowledge

The increased knowledge in pregnant women was influenced by two factors, namely the application material and application feasibility.

The material presented in the application

The material aspects of the Nutrition of pregnant women Nutrition application that affected the increase in knowledge are the information content, the language used in the information, the type of information, and the presentation of the information. The presentation of information includes information structure, detailed information, and pictorial elements. 
Information content

The information content presented in the Nutrition of pregnant women Nutrition education application is essential information that pregnant women need to know during pregnancy, especially for pregnant women with their first pregnancy. The information presented is not only important but also comprehensive so that respondents can get the information that is needed and complete. The information content of the Nutrition of pregnant women Nutrition application includes the definition of KEK, the causes of KEK, the impact of KEK, how to prevent KEK in pregnant women, the nutritional needs of pregnant women, and a sample of daily menus for pregnant women with normal weight.

Materials with important and comprehensive information can increase interest, namely, one's awareness to pay attention to something accompanied by a desire to know, study, and prove something further (Rusmiati, 2017). Interest can be created when a person feels that an object is related to his wants or needs. In this study, the respondent's interest in studying application material was influenced by the existence of essential and comprehensive information to meet the respondents' needs so that the respondent's knowledge increased.

\section{The language used in the material}

The language used in the material is the straightforward and concise language using general word choices as well. Also, technical terms of special scientific nature, such as cell differentiation, immunity, DNA formation, hypocalcemia, embryo, neonatal, and anemia contained in the application material for pregnant women nutrition education were all translated into statements that are not technical or scientific so that the information can be easily understood by respondents who do not have a scientific background in nutrition and pregnancy. The use of effective and efficient language is the main aspect to support one's ability to interpret, interpret, translate, understand, remember, relate facts, concepts, and experiences as well as estimates things in a learning process to form knowledge Ahmad (2017), which in this case is the respondent's learning ability to form knowledge about nutrition related to KEK.

Type of information

The type of information used in the Nutrition of pregnant women Nutrition education application material is conceptual information and scientific information. Conceptual information is information that provides an understanding of the concept of an event, while scientific information is information generated from research or other scientific interests (Capurro \& Hjørland, 2003). Conceptual information in the nutrition education application material for pregnant women includes the meaning of KEK, causes of KEK, the impact of KEK, and efforts to prevent KEK, while scientific information includes exposure to the types of nutritional needs of pregnant women and samples of the daily menu of pregnant women, the presentation of which is included with reference sources researchers and years of research.

With the presence of conceptual information, respondents have an understanding of the description of abstract ideas and processes between nutrition and KEK, which are then used to understand other information that is more concrete or more practical. Meanwhile, the existence of scientific information causes respondents' trust and confidence to learn the information provided in the application to be higher. There is information k Conceptual and scientific information is very useful for fulfilling the needs of respondents completely, so that it greatly affects the increase in respondents' knowledge about nutrition and KEK.

\section{Presentation of information}

The presentation of information on the application material for pregnant women nutrition education is carried out with a special-general structure (deductive), namely general information presented first then followed by specific information. The advantage of presenting information with such a structure is the laying out of the basic concept of thinking from the start so that the subsequent processes of understanding information take place more focused and directed (Ammase et al., 2015).

In this study, pregnant women were first given information about what KEK was and how to easily recognize $\mathrm{KEK}$, namely by paying attention to the circumference of the upper arm, then pregnant women were given information on the causes KEK and the impact of KEK. After information on the causes and impacts of KEK, the information is continued with efforts to prevent KEK and the nutritional needs of pregnant women. The information ends with a practical example of a one-day menu that pregnant women can apply. The presentation of information with this general-specific structure greatly influences the increase in knowledge of pregnant women because deductive information provides a more focused understanding of information so that information is more easily absorbed. Interesting and arouse the curiosity of pregnant women to continue to read more information. 
Apart from using a deductive structure, the information in the application material is also presented in detail. For example, on the causes of KEK, the information provided includes direct and indirect causes. The impact of KEK is given not only for pregnant women but also for fetuses and babies. Pregnant women are also given information about the prevention of KEK which includes prevention through nutrition, as well as prevention through other than nutrition. At the point of nutritional needs of pregnant women, in addition to explaining the function of each nutrient, adequate examples are also given regarding each source of nutrition. In the one-day menu sample point, there is information sharing for pregnant women in semester 1 and trimester 2. Each section on the daily menu includes detailed examples of meal schedules, menu names, portions, and portion conversions in household sizes, which are presented in the table makes it easy for respondents to find certain information quickly and accurately.

Through deductive structure and details, understanding of information is also facilitated by images presented with attractive colors and strong resolution. As can be seen in the application material, information about the nutritional needs of pregnant women is included with pictures of examples of sources of nutritional needs so that the information becomes more interesting and eliminates the boredom of the respondents when reading the material.

\section{Application eligibility}

The increased knowledge of pregnant women in this study is also influenced by the application of Nutrition of pregnant women Nutrition itself. The aspects of the application that influence are the aspects of the appearance (interface) and accessibility.

\section{Aspects of the display (interface)}

Increasing knowledge of pregnant women in this study is supported by several factors from the aspect of the application display. Based on the results of the assessment of IT experts used in this study, the interface aspects of the application include excellent design, good layout, good image clarity, excellent ease of application, good loading speed, RAM usage, is very good, display of themes and menu options is very good, good ease of guidance, good color composition, good feature compatibility, excellent application size, and excellent splash screen.

Accessibility aspects

Application accessibility concerns the convenience and ease of use of the application which includes the time, effort, and costs required to use the application. The Nutrition of pregnant women application can be accessed anytime and anywhere so it supports repetitive learning. Also, the Nutrition of pregnant women application can be accessed offline so no additional internet quota usage fees are required when using the application.

5) Nutrition education application for pregnant women to improve attitudes

Material aspects of the Nutrition of pregnant women application which include information content, language used in the information, types of information, and presentation of information (information structure, detailed information, and pictorial elements) and application aspects which include interface and accessibility aspects affect the increase in respondents' knowledge which in turn will shape the increase in respondent attitudes. Attitude is the readiness to react to objects in a certain environment as an appreciation of objects. Sufficient knowledge supports and strengthens the internalization of values in attitudes and strengthens the readiness to give res the corresponding pound (Rajaratenam et al., 2014). The value referred to in this case is the value of the trust (true/ false) on the statement points given in the attitude questionnaire.

6) Nutrition education application for pregnant women to improve behavior

From the results of data analysis, it is known that knowledge, attitudes, and behavior are interrelated. The higher the knowledge and attitudes, the better the behavior will be Rahayu et al. (2014), as seen in this study. Knowledge is a very important domain for the formation of one's actions. Behavior-based on knowledge will be more resilient than behavior that is not based on knowledge, likewise with attitude. Attitude is a positive or negative evaluative response to a value which then crystallizes as a potential reaction or behavior towards the object.

The increased eating behavior of pregnant women in this study is an effect of the accumulation of knowledge and attitudes that have previously increased. Increasing essential knowledge about the nutrition of pregnant women as a whole directs the internalization of values that shape attitudes, and attitudes, in the end, directs the actual response of pregnant women to all objects and situations related to nutrition of pregnant women, which in this case is the eating behavior of pregnant women in the form of menu selection and determination of meal portions at each mealtime. 
The results of this study are in line with research conducted by Zaki \& Sari (2019), in their research entitled "Social Media-Based Nutrition Education to Increase Knowledge and Protein Energy Intake with Less Chronic Energy (KEK)" shows that giving nutrition education interventions 8 times during 2 weeks obtained the results of an increase in knowledge of $74.1 \%$ in the urban group and the rural group $85.7 \%$, as well as an increase in the average energy intake in the urban and rural groups.

Also, the results of this study are in line with research conducted by Perdana et al. (2018) and Sayekti et al., (2020). Sayekti et al. (2020), in their research entitled "Education Media for Android-Based Pregnancy Hazard Signs to Increase Knowledge of Pregnant Women", it was found that the provision of Android-based Pregnancy Hazard Education Media Interventions can increase maternal knowledge by $15.50 \%$. Who found that android-based nutrition education media in improving balanced nutritional behavior is better than other media as evidenced by the results before the intervention of school children having good knowledge, positive attitudes, and well-balanced nutrition practices successively at $72.9 \%, 78.5 \%, 54.9 \%$. After the intervention, knowledge, attitudes, and practices increased by $11.8 \%, 5.5 \%$ and $15.9 \%$.

\section{Conclusion}

Based on the results of research and data analysis that has been carried out on the effect of nutrition education with Android-based application media on chronic energy deficiency (KEK) on the knowledge, attitudes, and behavior of pregnant women, the conclusion can be drawn is that there is an increase in the knowledge, attitudes, and behavior of pregnant women about chronic energy deficiency (KEK) in Meo - Meo Health Care Center, Baubau City. Therefore, the researcher put forward several suggestions that pregnant women will continually use the Nutrition of pregnant women application. Besides, midwives' colleagues can further socialize and implement education with the Nutrition of pregnant women application media to cover a wider field of nutrition and pregnancy. Besides, further researchers are encouraged to use two groups, namely the intervention group and the control group to see the differences in knowledge, attitudes, and behavior between the two groups as well as adding more materials for much easier understanding such as videos.

\section{Acknowledgments}

I would like to thank the supervisors who took their time in the preparation of this research and my special appreciation to the head of the Meo-Meo Public Health Center, midwives, and all pregnant women in the work area of the Meo-Meo Public Health Center who have been willing to become respondents. I also thank my parents, husband, and children who always pray, support, and motivate researchers.

\section{References}

Agustian, E. N. (2010). Hubungan antara asupan protein dengan kekurangan energi kronik (KEK) pada ibu hamil di kecamatan Jebres Surakarta.

Ahmad, A. (2017). Penerapan Permainan Bahasa (Katarsis) untuk Meningkatkan Keterampilan Membaca Siswa Kelas Iva SD Negeri 01 Metro Pusat. EduHumaniora| Jurnal Pendidikan Dasar Kampus Cibiru, 9(2), 75-83.

Ammase, S., Hidayat, M. Y., \& Jusriana, A. (2015). Pendekatan Pembelajaran Deduktif Dan Pembelajaran Induktif Untuk Meningkatkan Keterampilan Bertanya Pokok Bahasan Pemuaian Kelas Vii Smp Negeri 21 Makassar. Jurnal Pendidikan Fisika, 3(1), 1-4.

Andriani, Z. (2015). Gambaran status gizi ibu hamil berdasarkan ukuran lingkar lengan atas (LILA) di Kelurahan Sukamaju Kota Depok (Bachelor's thesis, UIN Syarif Hidayatullah Jakarta: Fakultas Kedokteran Dan Ilmu Kesehatan, 2015).

Batalden, P. B., \& Stoltz, P. K. (1993). A framework for the continual improvement of health care: building and applying professional and improvement knowledge to test changes in daily work. The Joint Commission journal on quality improvement, 19(10), 424-447. https://doi.org/10.1016/S1070-3241(16)30025-6

Bath, S. C., Steer, C. D., Golding, J., Emmett, P., \& Rayman, M. P. (2013). Effect of inadequate iodine status in UK pregnant women on cognitive outcomes in their children: results from the Avon Longitudinal Study of Parents and Children (ALSPAC). The Lancet, 382(9889), 331-337. https://doi.org/10.1016/S0140-6736(13)60436-5

Capurro, R., \& Hjørland, B. (2003). The concept of information. Annual review of information science and technology, 37(1), 343-411.

Erlinawati, E., \& Masturo, T. (2018). Hubungan Anemia Ibu Hamil Dengan Kejadian Kekurangan Energi Kronis (KEK) Di Wilayah Kerja Puskesmas Tapung Perawatan Tahun 2017. Jurnal Doppler, 2(1). 
Farida, F., Sari, H. P., Sulistyaning, A. R., \& Zaki, I. (2020). Pengaruh Pendidikan Gizi terhadap Sikap, Asupan Zat Gizi Makro, dan Air pada Anggota Pramuka. Nutri-Sains: Jurnal Gizi, Pangan dan Aplikasinya, 3(2), 60-72.

Garshasbi, A., \& Zadeh, S. F. (2005). The effect of exercise on the intensity of low back pain in pregnant women. International Journal of Gynecology \& $\quad$ Obstetrics, 88(3), 271-275. https://doi.org/10.1016/j.ijgo.2004.12.001

Hayurani, H., Hamnah, H., Rachmawati, U. A., \& Suherlan, E. (2019). HelloCare: Aplikasi Manajemen Pengetahuan Berbasis Android Untuk Tenaga Kesehatan. Jurnal Teknologi Informasi YARSI, 6(1), 25-34.

Kartikasari, B. W., Mifbakhuddin, M., \& Mustika, D. N. (2013). Hubungan pendidikan, paritas, dan pekerjaan ibu dengan status gizi ibu hamil trimester III di Puskesmas Bangetayu Kecamatan Genuk Kota Semarang tahun 2011. Jurnal Kebidanan, 1(1), 9-18.

Krisdiani, A. F., Sufyan, D. L., Ilmi, I. M. B., \& Syah, M. N. H. (2020). Pengaruh Edukasi Melalui Twitter Thread Terhadap Pengetahuan Gizi Seimbang Remaja di SMP Harjamukti Depok. IKESMA, 16(2), 95-102.

Malterud, K. (2001). The art and science of clinical knowledge: evidence beyond measures and numbers. The Lancet, 358(9279), 397-400. https://doi.org/10.1016/S0140-6736(01)05548-9

Mulyani, S., Subiyanto, A. A., Anantanyu, S., Respati, S. H., \& Wiboworini, B. (2017). Path analysis: knowledge, motivation factor, and their relationship with readiness to provide exclusive breastfeeding among pregnant women. International research journal of management, IT and social sciences, 4(1), 8-14.

Nurhemah, N. (2018). Pengaruh Penggunaan Smartphone Dan Kelas Virtual Terhadap Pengetahuan Konseptual Dan Kemandirian Belajar Siswa Sma Negeri 2 Kota Tangerang Selatan. PEDAGOGIA, 16(1), 1-9.

Perdana, F., Madanijah, S., \& Ekayanti, I. (2018). Pengembangan media edukasi gizi berbasis android dan website serta pengaruhnya terhadap perilaku tentang gizi seimbang siswa sekolah dasar. Jurnal Gizi dan Pangan, 12(3), 169-178.

Rahayu, C., Widiati, S., \& Widyanti, N. (2014). Hubungan antara Pengetahuan, Sikap, dan Perilaku terhadap Pemeliharaan Kebersihan Gigi dan Mulut dengan Status Kesehatan Periodontal Pra Lansia di Posbindu Kecamatan Indihiang Kota Tasikmalaya. Majalah Kedokteran Gigi Indonesia, 21(1), $27-32$.

Rajaratenam, S. G., Martini, R. D., \& Lipoeto, N. I. (2014). Hubungan tingkat pengetahuan dan sikap dengan tindakan pencegahan osteoporosis pada wanita usila di Kelurahan Jati. Jurnal Kesehatan Andalas, 3(2).

Rusmiati, R. (2017). Pengaruh Minat Belajar Terhadap Prestasi Belajar Bidang Studi Ekonomi Siswa MA AL FATTAH Sumbermulyo. Utility: Jurnal Ilmiah Pendidikan dan Ekonomi, 1(1), 21-36.

Sabilla, M., Mustakim, F. S., Ariasih, R. A., Efendi, R., \& Febrianti, T. (2020, October). Community Services In Pandemic Situation: Preparing Quality Of Life In Middle Age Group Through Social Media Education "KULWAP”(Kuliah Whatsapp). In International Conference On Health Science (pp. 20-25).

Sayekti, W. N., Syarif, S., Ahmad, M., Nurkhayati, E., \& Suciati, S. (2020). Media Edukasi Tanda Bahaya Kehamilan Berbasis Android Untuk Meningkatkan Pengetahuan Ibu Hamil. Oksitosin: Jurnal Ilmiah Kebidanan, 7(2), 76-86.

Sugiyono. (2007). Penelitian Kualitatif dan Kuantitatif. Rineka Cipta.

Sugiyono. (2008). Metode penelitian pendidikan:(pendekatan kuantitatif, kualitatif dan $R \& D$ ). Alfabeta.

Sungurtekin, H., Sungurtekin, U., Hanci, V., \& Erdem, E. (2004). Comparison of two nutrition assessment techniques in hospitalized patients. Nutrition, 20(5), 428-432. https://doi.org/10.1016/j.nut.2004.01.006

Suryani, A. D., \& Ardian, Q. J. (2020). Rancang Bangun Identifikasi Kebutuhan Kalori Dengan Aplikasi Go Healthy Life. Jurnal Teknologi dan Sistem Informasi, 1(1), 47-56.

Tempali, S. R., \& Sumiaty, S. (2019). Peranan Edukasi Bidan dalam Mencegah Kurang Energi Kronis (KEK) pada Ibu Hamil di Provinsi Sulawesi Tengah. Jurnal Bidan Cerdas, 1(2), 82-86.

Wild, T., Rahbarnia, A., Kellner, M., Sobotka, L., \& Eberlein, T. (2010). Basics in nutrition and wound healing. Nutrition, 26(9), 862-866. https://doi.org/10.1016/j.nut.2010.05.008

Yulianasari, P., Nugraheni, S. A., \& Kartini, A. (2019). Pengaruh Pendidikan Gizi Dengan Media Booklet Terhadap Perubahan Perilaku Remaja Terkait Pencegahan Kekurangan Energi Kronis (Studi pada Remaja Putri SMA Kelas XI di SMA Negeri 14 dan SMA Negeri 15 Kota Semarang). Jurnal Kesehatan Masyarakat (e-Journal), 7(4), 420-428.

Zaki, I., \& Sari, H. P. (2019). Edukasi gizi berbasis media sosial meningkatkan pengetahuan dan asupan energiprotein remaja putri dengan kurang energi kronik (KEK). GIZI INDONESIA, 42(2), 111-122. 